DOI: 10.1515/auseur-2016-0017

\title{
Measurability of Social Development Reflections on the Applicability of Social Progress Indices with Reference to Brexit
}

\author{
János IVANYOS \\ Budapest Business School, \\ Finance Department of the Faculty of Finance and Accountancy \\ ivanyos@content.hu \\ Éva SÁNDOR-KRISZT \\ Budapest Business School, Institute of Methodology \\ kriszt.eva@uni-bge.hu
}

\begin{abstract}
The question is how the global and local economic actors' innovationbased local social and environmental objectives and results can modify the social cohesion strategies, how the disparities in economic and social development can be measured and evaluated at regional level in addition to a comparison across countries. We have seen that any one indicator in itself is not enough since it does not provide sufficient explanation for either the development disparities or their reasons. Anyway, in addition to GDP per capita, it is worth applying - and it is important to apply - such indicators as SPI and Well-Being, and various indices of social progress.
\end{abstract}

Keywords: economic development, purchasing power parity, GDP, Social Progress Index, country-level comparison, EU regional policy

'Not everything that counts can be counted, and not everything that can be counted counts.' (from the wall of Einstein's office at Princeton)

\section{Introduction}

One of the most commonly used measures of economic development is GDP per capita. It is based on gross domestic product (GDP), a measure for the output of economic activity. GDP is the value of all goods and services produced less the value of any goods or services used in their creation. GDP per capita can be calculated from this corrected with population. Comparisons between countries can be made by calculating with the internationally accepted methodology of purchasing power parity (PPP). 
PPP is a territorial price index and can be calculated from the price ratios of the same goods and services across countries. With a comparison of PPPs, the differences in price levels between countries are eliminated, which allows meaningful volume comparisons.

GDP per capita is a commonly used indicator for a country's average standard of living. This, however, can be considered an oversimplification.

To measure well-being, it is not enough to examine merely the accumulation of material goods. Several factors allowing objective measurement are known that do or at least may affect people's well-being such as life expectancy at birth, infant mortality, housing conditions, access to clean drinking water, education, literacy, degree of freedom and democracy, and the relationship between natural environment and well-being. It is for this measurement that the methodology of Well-Being index calculation has been formulated.

Some kind of element, however, is missing from each approach, and the survey may seem to be one-sided. So, demand has already appeared for establishing complex indicators or systems of indices that break with the traditional onesided attitude and do not focus on either the goods produced by a society or the incomes but demonstrate social progress as a complex process with man and demand for living a better life and achieving social well-being in its centre.

The Hungarian Central Statistical Office, in line with the principles laid down by the OECD, has also started to develop a system of statistical indices that - we think - describe processes considerably affecting social changes. References to it can be found under Social Progress Index.

Indicators based on the same principles allow - in addition to comparisons across countries - regional comparisons too, which - in a given case - will better help to reveal the reasons for differences in development and enable deeper analysis.

\section{Country-Level Comparison of Economic Development}

The most commonly used indicator for overall comparisons of economic development is GDP per capita calculated at purchasing power parity (PPP). And Figure 1 also shows the changes between 2005 and 2015 (EU-28 = 100; calculated at PPP).

Researchers also try to describe differences in development with various spatial images seeking to reveal some homogeneity and cohesion in development, such as the so-called Pentagon image or the Cross Banana image, etc. 


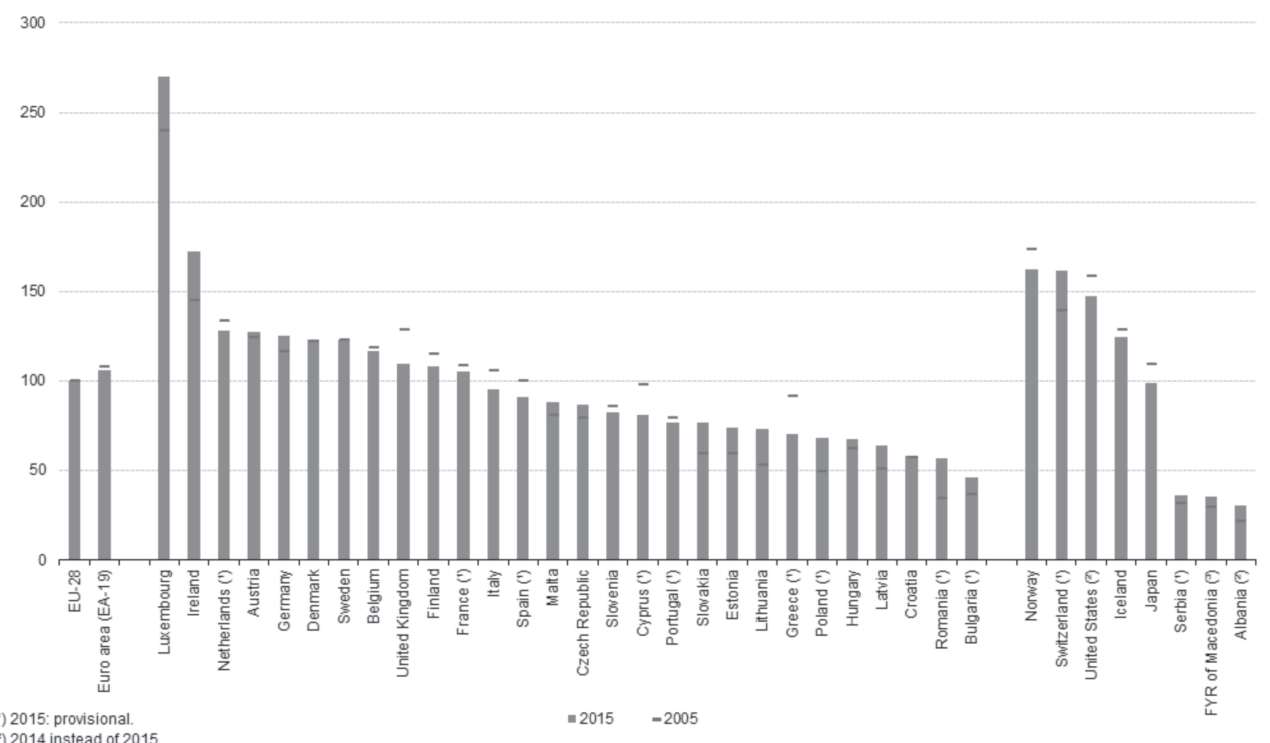

Figure 1. Changes in GDP per capita in countries of Europe between 2005 and 2015

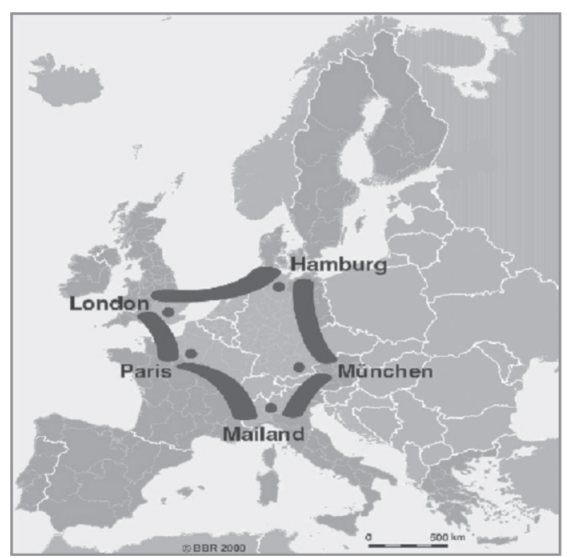

Figure 2. Pentagon

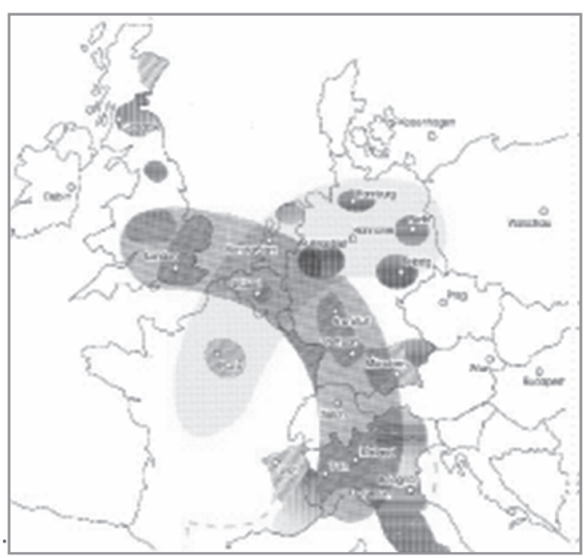

Source: Pál Szabó 2009

Figure 3. Cross Banana

According to a certain approach, Europe cannot be described with a formalized spatial pattern, yet regions need to be categorized. 'Since individualities cannot be handled by the EU's regional policy due to the vast territory: the delimitation of assisted regions can be based upon statistics rather than a city view or regional image’ (Szabó 2009). 
Compared to the popular spatial figures, an analysis of regional-level (NUTS 2) statistics can provide more realistic explanation for political and social orientations not necessarily interpretable with economic rationality, as we could also see e.g. in connection with Brexit. It should also be emphasized in advance that various economic development and well-being statistics compared at a higher (e.g. country) level of aggregation and separately from the other indicators can - similarly to formalized spatial models - show a picture (and correlations) different from the reality of lower regional levels, which can also be seen in the nation-wide totalling of local referendum results.

\subsection{Country-Level Comparison of Well-Being}

After the Stiglitz Report published in 2009 - in which the renowned economics professor queried GDP's omnipotence -, a lively debate arose between statisticians and economists about measuring social well-being. The debate was especially hot about the role of GDP, i.e. gross domestic product. It should be noted that statisticians have never claimed GDP would be the only measure for the development of a society and the well-being of people living in it. GDP is one slice of the big system of national accounts and an important but not exclusive indicator of economic development, let alone of well-being. GDP as an indicator is widely used and accepted even today, primarily instead of national income, which is much more difficult to work out. It is calculated according to an established and internationally prescribed methodology. Its calculation methodology is laid down in EU law.

Meanwhile, an extensive methodology for calculating the Well-Being Index has also evolved. So, in addition to the possibility of objective measurement, there is also a so-called subjective well-being (SWB) measurement. Its methodology is currently being formulated. Tamás Gáspár distinguishes three levels of measuring SWB: the level of pleasure, the level of involvement or flow-state, and the level of meaningful life. Of course, the three levels are structured hierarchically, and efforts are made to formulate measures for the studied phenomenon with the help of numerous empirical surveys and databases (Gáspár 2013).

The methodology is still very diverse, but good practices have been consistently applied for years such as the survey by the London-based Legatum Institute, which even ranks countries. They consider 89 variables in their ranking. Explanatory variables include per capita GDP, percentage of the active population, security of Internet servers, but also subjective factors such as how well-rested citizens feel. The 89 variables are then further examined in 8 categories, so to say clusters, and even within the categories they rank the countries. The 8 categories are: Economy, Education, Entrepreneurship and Opportunity, Governance, Health, Personal Freedom, Safety and Security, and Social Capital. 
In 2015, the following countries ranked in the top five: 1. Norway, 2. Switzerland, 3. Denmark, 4. New-Zealand, 5. Sweden. Hungary was ranked $45^{\text {th }}$. Beyond the absolute ranks - once a longer time series is available -, it will also be worth analysing changes over time.

\subsection{Social Progress Indices}

A system of social indicators, or social indices started to be developed in the middle of the $20^{\text {th }}$ century. One of the best known social indicators is the Human Development Index (HDI), worked out under the UN's Development Programme. HDI has three dimensions: health, education, and standard of living, having a highly composite measurement system based on at least four indicators according to the original definition. So, it is not widely used as yet (Köpeczi-Boócz 2011).

In Hungary, a complex index system designed to measure social progress is being developed under the control of the Central Statistical Office. Participating in this work is the Hungarian Academy of Sciences, while representatives of the main professional organizations are also involved.

The main groups of the currently used index system are as follows:

1. Economic Ratios

1.1. Level of Development and Growth

1.2. Efficiency, Competitiveness, and Stability

1.3. Knowledge-Based Economy

1.4. Infrastructure

2. Social Indicators

2.1. Population and Family

2.2. Education

2.3. Labour Market

2.4. Status of the Young

2.5. Status of the Elderly

2.6. Financial Status and Consumption

2.7. Housing

2.8. Health

2.9. Social Safety Net

2.10. Culture and Leisure

2.11. Public Security

3. Environmental Indicators

3.1. Climate Change and Energy

3.2. Natural Resources

3.3. Sustainable Production

It is apparent how complex the index system is and how much care is required already for country-level comparisons. We also think the synthesized indicators 
can hide a lot, so it is worth examining the differences in development more deeply at both the economic and social level. And thereafter we should search into the causes of differences. Of course, even significantly different rankings obtained with the various indicators can help the analyst draw important conclusions.

\section{Certain Economic and Social Indicators and Their Regional Political Aspects with Reference to Brexit}

Several reasons are listed with regard to the Brexit results, and big differences are visualized between the various regions of the United Kingdom. Differences in the level of development are often referred to as one of the main reasons for the differences of opinion. Hereafter, we would like to examine whether a political orientation so different from that of the EU member countries with similar levels of economic and social development can be attributed to differences measurable at a regional level.

When examining regional policy, we usually presume that the achievements of social, political, and economic integration processes - which promote the development of a local economy operating in the global market - provide sufficient motivation and support among the population of voting age so that the intention of actually accomplishing an exit from the integration should not come up seriously.

Apart from the outcome of the Brexit decision, we must reflect on what real processes can be detected behind the 'popular will' seemingly manifested against economic rationalities in one of the oldest parliamentary democracies, since their recognition can help us not only to handle the integration problems affecting the EU but - in a wider sense - also to address global economic, social, and environmental sustainability issues.

We will also be able to see what wider factors interpretable also at European or international level we should reasonably face instead of identifying those voting against integration as low-skilled and belonging to older age-groups.

To start with, by reviewing some socio-economic indicators and immigration data measured at regional level, we will try to draw conclusions - supported by data and somewhat divergent from the popular statements - on the basis of comparisons with the European core area, which is most closely connected to the UK also geographically (including Germany, France, the Netherlands, Denmark, Belgium, and Ireland, linked by a thousand threads with the UK).

Figure 4 shows development levels by GDP down to a depth of NUTS 2 regions in the selected countries. The only significant variance is (inner) London's extraordinarily high GDP rate, which represents a significant disparity not only within the country but also compared to the other member states' leading regions. 
Considering that the percentage of those desiring to remain within the EU was in a vast majority here (in contrast to the other regions of England), a significant economic lag behind the central region (a difference in development level) can be a factor to be definitely taken into account.

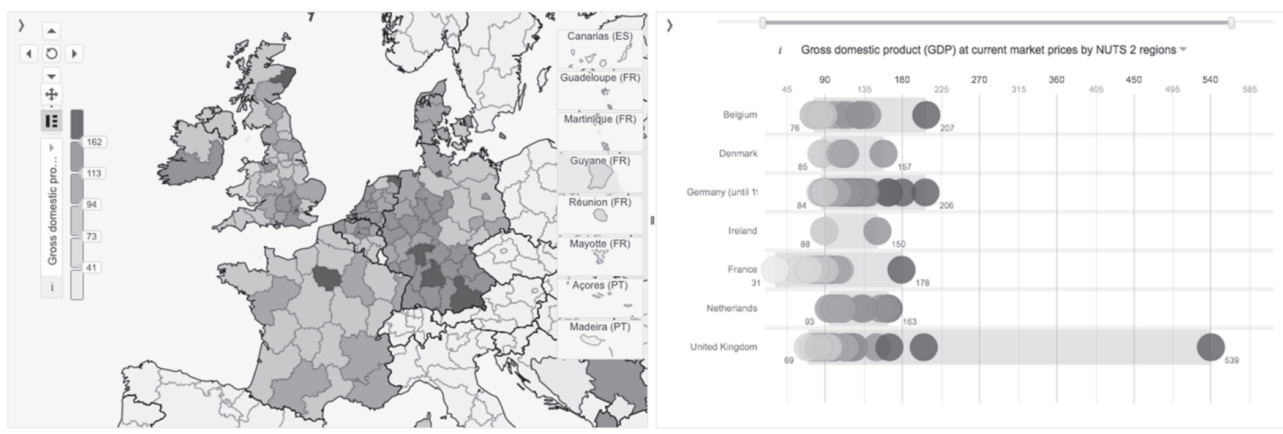

Source: Eurostat 2014 (http://ec.europa.eu/eurostat/cache/RSI/)

Figure 4. Economic development in the NUTS 2 Regions of Selected Countries (by GDP)

Unemployment trends by region show an interesting picture. A consolidated and actually very favourable picture, very similar to Germany in this respect, is characteristic of the UK - in contrast to France, Belgium, and Ireland, belonging to the same category of economic development. This implies, on the one hand, that at a given (relatively high) level of economic development a higher unemployment rate reflecting an uncertain economic situation cannot be considered a significant factor against integration aspirations. On the other hand, a high employment rate in itself is neither a guarantee of the support of integration aspirations nor a direct indicator of a development disparity.
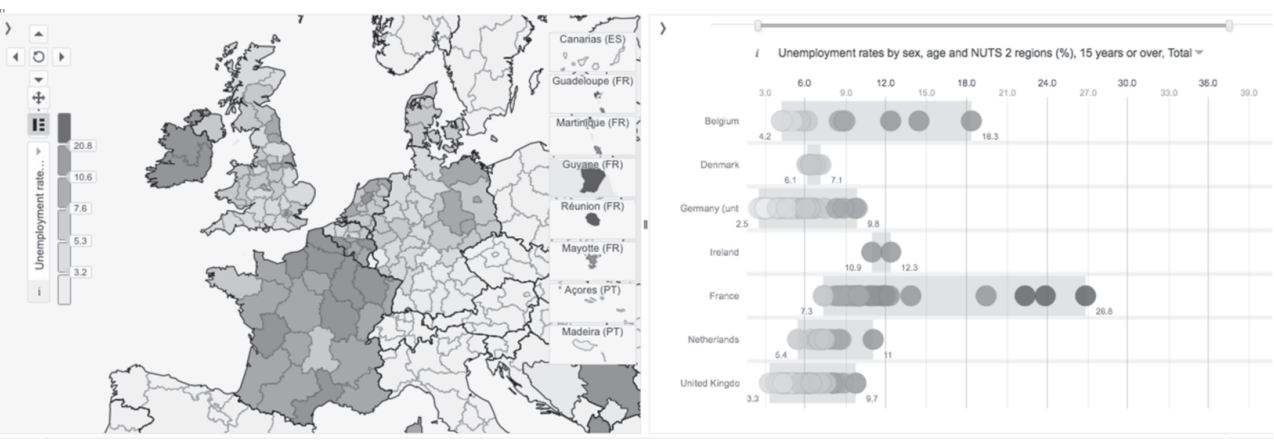

Source: Eurostat 2014 (http://ec.europa.eu/eurostat/cache/RSI/)

Figure 5. Unemployment rates in the NUTS 2 Regions of selected countries (age: 15-65) 
According to a frequently heard opinion, lower educational attainment also hides behind anti-integration. Well, actually, in a cross-European comparison (e.g. compared to Germany), UK has a significant advantage in respect of tertiary educational attainment. So, the rejection of integration cannot be explained by lower educational attainment, at least when differences across countries are considered.

It can be seen in Figure 6 that (inner) London stands out from the domestic as well as the international field in terms of both GDP per capita and higher educational studies. This leads us to conclude that a higher percentage of people with tertiary education means a clearly stronger support for the integration processes typically in the regions with outstanding incomes. So, for the measurement of differences in development it seems to be worth including the income levels as well.

In areas lagging behind the strong central region, a higher educational level can have a less decisive role in supporting integration.

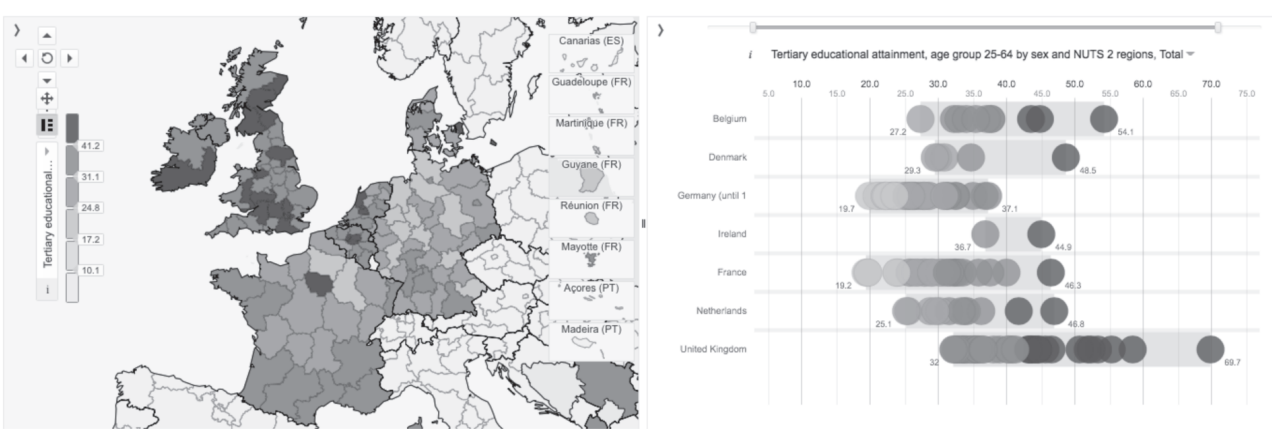

Source: Eurostat 2015 (http://ec.europa.eu/eurostat/cache/RSI/)

Figure 6. Percentage of people with tertiary education in the NUTS 2 regions of selected countries (age: $25-64$ )

Based on UN Population Division data for 2015 (ref.: http://metrocosm.com/ get-the-data/), of the UK's population of $65 \mathrm{M}$, almost 5 million live abroad as opposed to the 8.5 million foreign immigrants (or, to put it more nicely, 'expats').

At $8 \%$, the ratio of British citizens living outside their home country in the largest number from EU member states (apart from the 19\% ratio of the Irish) is considerably higher than the German (5\%), French (3\%), Belgian (5\%), Dutch (6\%), and Danish (4\%) indicators.

The $13 \%$ ratio of immigrants to resident population roughly equals the $12 \%$ ratio for France, Belgium, and Holland, but it is below Germany's 15\% and Ireland's 16\% ratios. Denmark with its 10\% ratio lies a little outside the surveyed countries. 


\section{EU Member States}

Number of citizens living outside their home country

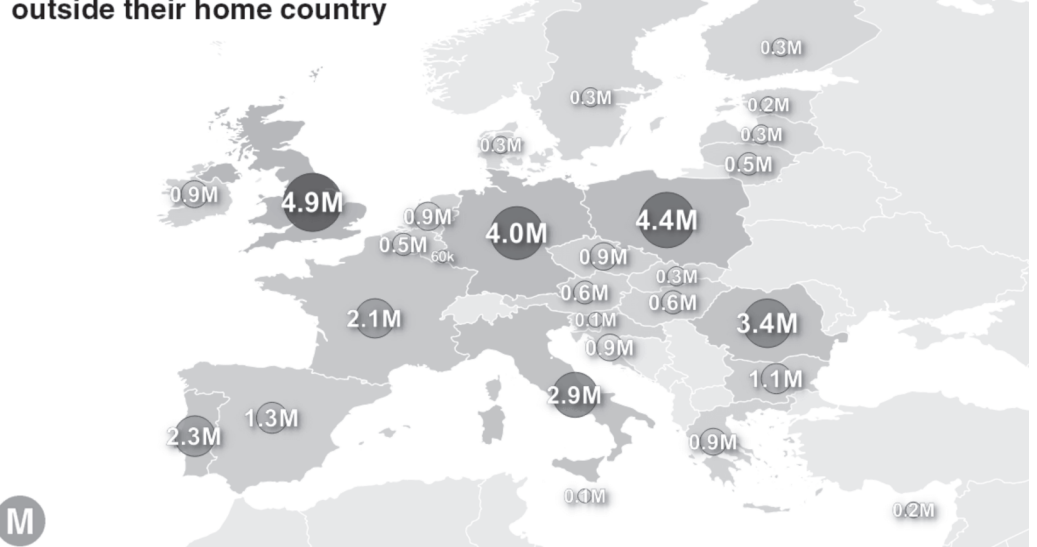

Source: http://metrocosm.com/eu-diaspora-map/ (with reference to UN Population Division data)

Figure 7. Number of EU member states' citizens living abroad in 2015

Immigration - in international comparisons - does not actually cause significant fear in the UK's society. This is also indicated by the fact that, although according to a survey by Ipsos MORI in 2014 the over one thousand British respondents aged 16-64 also overestimate negative phenomena (or phenomena considered negative) in public perceptions of social issues (except for life expectancy) compared to facts, the deviation from reality is by no means so significant as e.g. in Eastern Europe (or Japan and South Korea), but it is actually similar to that in the European core countries (Ipsos MORI 2014).

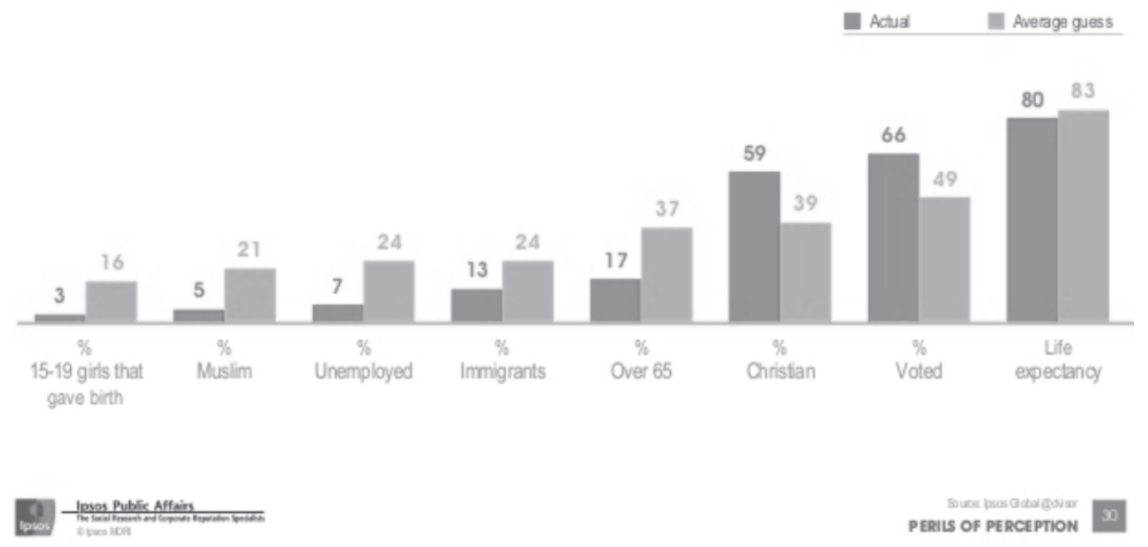

Source: https://www.ipsos-mori.com/researchpublications/researcharchive/3466/Perceptionsare-not-reality-Things-the-world-gets-wrong.aspx

Figure 8. Guesses by British respondents on certain social issues vs facts 
Relying upon these findings, in comparison with the European core countries, we should not consider the effect of anxiety about immigration on the Brexit decision extremely important either.

\section{New Approach to Social Progress Indicators: Social Progress Index}

The Social Progress Imperative, also renowned under the name of Michael E. Porter, originally developed an index system for the social progress of nations. Today, however, the methodology is already applied at regional and even municipal levels. Based on the methodological summary for the European regions (also considering European peculiarities), we have found it worth investigating further (European Commission DG Regional 2016).

The Social Progress Index framework considers 4 components along each of the following 3 dimensions: Basic Human Needs, Foundations of Well-Being, and Opportunity. Each component is measured through several indicators.

Four key principles guided the selection of indicators:

- they are exclusively social and environmental indicators (no economic measure is included);

- they measure outcomes and not inputs;

- they are relevant to all the countries (or regions);

- they allow the determination of direct intervention steps.

By excluding economic indicators, the index becomes suitable for a systematic analysis of the relationship between social progress and economic progress (e.g. to define the connection between per capita GDP figures and SPI indicators). In line with the above four principles, the Social Progress Index (SPI) - complementary to GDP indicators - allows a thoroughly elaborated and comprehensive measurement of sustainable development widely applicable in practice. The Social Progress Imperative published its Social Progress Index 2016 Report in June 2016 (Social Progress Imperative 2016a), where the following figure presenting the level of development by GDP and the level of social progress across countries is also included:

An interesting conclusion can be drawn from the shape of the curve. With a (relatively high) level of economic development achieved, the social progress scores do/can decreasingly result from the stepping up or revving up of economic performance. That is, the existence and enforcement of a more conscious social and environmental strategy increasingly tends to be the driving force in the 'formation' of an advantage realizable on account of social progress. 


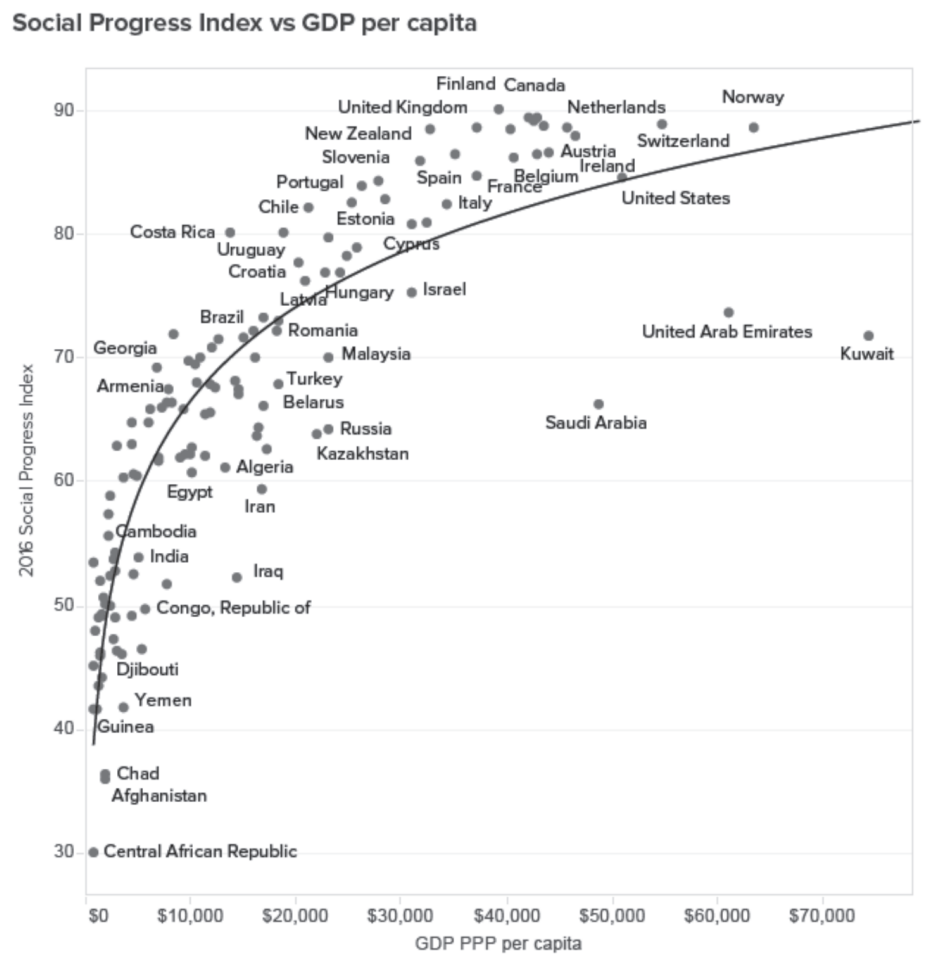

Source: Social Progress Imperative 2016a

Figure 9. Social Progress Index vs economic development by GDP across countries

Compared to the previous (2015) SPI Report, the UK has increased its relative lead over the otherwise economically better-performing EU-core. While the EUcore (apart from Holland) has lost from its social progress position, the UK has improved its ranking (getting ahead of Iceland and New Zealand, it has jumped from the $11^{\text {th }}$ to the $9^{\text {th }}$ place, whereas in respect of GDP per capita it was only ranked $16^{\text {th }}$ in 2014). The current SPI values are generated from the data of the previous 3 years; therefore, we can speak about a trend of change. It remains to be seen how the UK will be able to maintain and realize this lead in social progress under circumstances changed by the Brexit referendum.

It is less a divergence of the individual districts'/regions' economic development but rather the generations' divergent experience, judgement, and benefit of the achievements and prospects of social progress that is behind the outcome of the Brexit referendum and the subsequent political changes within the UK. In this respect, no wonder that the majority of the elderly (over 45) and, on a European scale, by no means underqualified population - presumably more preferring 
the achievements in social progress against economic growth - voted for exit or rather against integration.

Higher commitment by younger generations to integration can well be explained by the (extra) income resulting from higher economic performance - otherwise, with a view to their career, absolutely understandably - being more important for them than preserving a favourable (in comparison to other countries) social progress position already achieved. All this points out one of the significant contradictions deriving from global economic competition, i.e. beyond a certain level the enhancement of global competitiveness and the economic growth are realized to the detriment of social cohesion, one of the striking consequences of which is a decline of the middle classes, evolved throughout centuries in certain developed societies, even in the case of the most powerful economies (see the US).

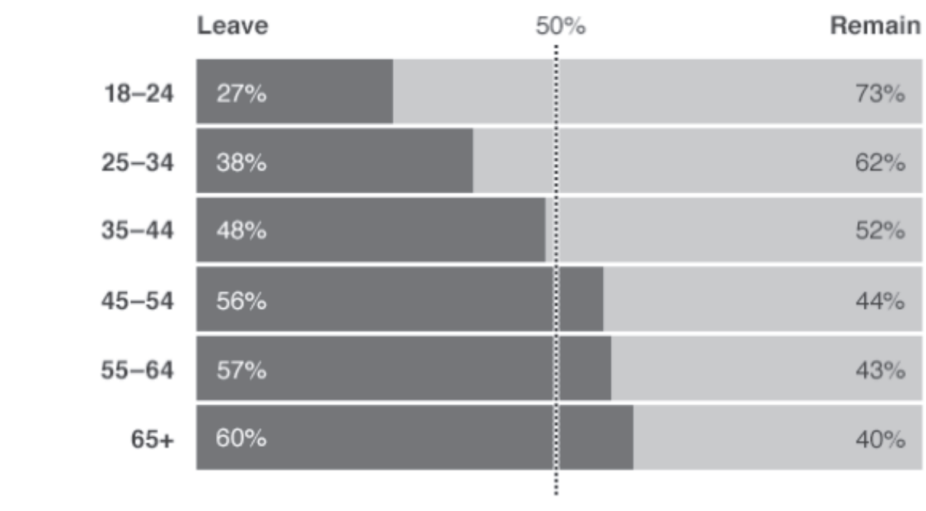

Source: Lord Ashcroft Polls

Source: BBC (http://www.bbc.com/news/uk-politics-36616028)

Figure 10. Brexit referendum results by age-group

Social cohesion, however (based on social progress results achieved so far), may also be of higher significance than a change in economic performance with a view to achieving sustainability objectives more closely linked to social and environmental progress. In this respect, the British - according to historical experiences and the achieved social progress results - are doing quite well.

In a nation-wide manifestation of political will, both the central regions (mostly linked to a given country's capital city and economic centre) with an extremely outstanding level of economic development by GDP having real interests in supporting international integration (see Inner London) and the regions lagging behind in terms of economic growth (such as certain regions in Wales and Scotland) having aspirations to join the more developed areas may remain in a minority if the majority of eligible voters prefer to keep the - more important 
for them - social and environmental achievements rather than opting for some benefits resulting from economic growth (less) realizable by them.

It should also be noted, however, that at a higher level of economic development there are few examples of the loss of economic competitive advantages having an 'instantaneous' reaction to preferences for the retention of social and environmental advantages.

The overwhelming majority of global Sustainable Development Goals adopted by the UN in 2015 (United Nations General Assembly 2015) can be linked with the improvement of social progress results in addition to or - at a high level of development achieved - rather instead of economic growth. For that matter, the high priority of sustainability goals can already be observed in handling not just real social needs but also business risks involved and increasingly recognized in the operation of global corporate value chains (see the concept of "creating shared value' propagated by Porter and Kramer) (Porter-Kramer 2011).

The following question can be rightly raised with respect to arguments for economic advantages resulting from strengthening inter-regional integration: How can we achieve a more favourable social progress result compared to the present level of economic development, and how can we realize and maintain this advantage? This question also arises globally since - according to a relevant Deloitte analysis - it is most likely that the Sustainable Development Goals adopted by the UN in 2015 cannot be met by 2030 merely on the basis of the GDP growth forecast (Deloitte 2015).

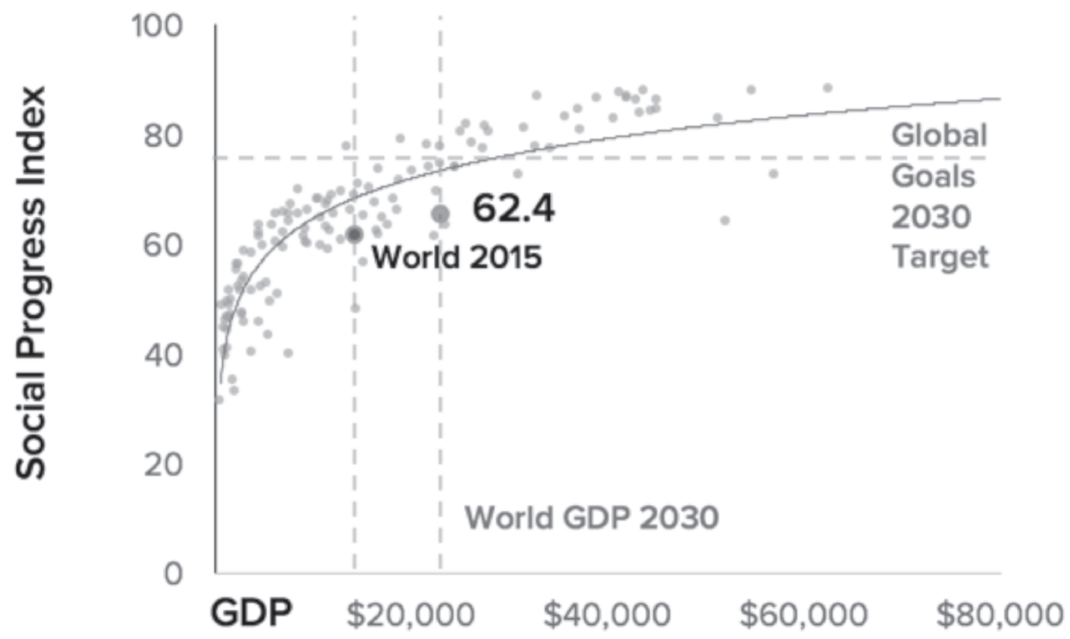

Source: http://www.ted.com/talks/michael_green_how_we_can_make_the_world_a_better_ place_by_2030?linkId=17951655

Figure 11. SPI for global sustainable development goals and SPI forecast relative to per capita GDP expected in 2030 
In his answer to the above challenge, Michael Green, an expert from the Social Progress Imperative, points out the incidental development opportunities deriving from the improvement of social progress results (Green 2015). In his opinion, the present regression curve (based on 'business as usual') can be positioned higher with the implementation of the states' and regions' development programmes for conscious social progress (promised by the member states' leaders by accepting global sustainable development goals in 2015) and the - either voluntary or forced - change in business actors' preferences, certainly under close social control (continuous measurement and accountability).

Behind the economic actors' corporate social responsibility (CSR) endeavours, there are - for the most part - business motivations instead of an intention to identify and meet real social needs. The approach of 'creating shared value' (CSV) focuses on how business interests and social needs can as well coincide, moreover, result in further (increasing) business profits. Along the CSV approach, the key members of global corporate value chains - similarly to state and community actors - can become participants in local programmes and initiatives serving social progress.

A great dilemma of sustainable development is whether social progress can exist without (also locally) measurable economic growth. As you can see in Figure 9, at country level, there is a strong correlation (of around $80 \%$ ) between GDP figures and SPI, measuring social progress, excluding economic performance indicators. Nevertheless, there is high variance in social progress results between countries and regions at a given GDP level. Studying the competitiveness and spatial aspects of social progress indices, we can find that the better than average social development levels of the countries and regions representing the same economic development level can provide a relative and temporary competitive advantage for the businesses in the region. Therefore, more favourable conditions are also granted for economic growth.

On the basis of the 2016 EU Regional Social Progress Index, published on 11 October 2016, it can be proved, on the one hand, that there is a very close relationship between social progress development and competitiveness also at regional level (see Figure 12), but, on the other, it can also be observed that compared to a similarly strong correlation between GDP and social progress at country level - in regional comparisons the closeness of relationship with GDPbased development is weakening, with household income taking its place as a stronger explanatory factor (see Figure 13) (Social Progress Index 2016b). 


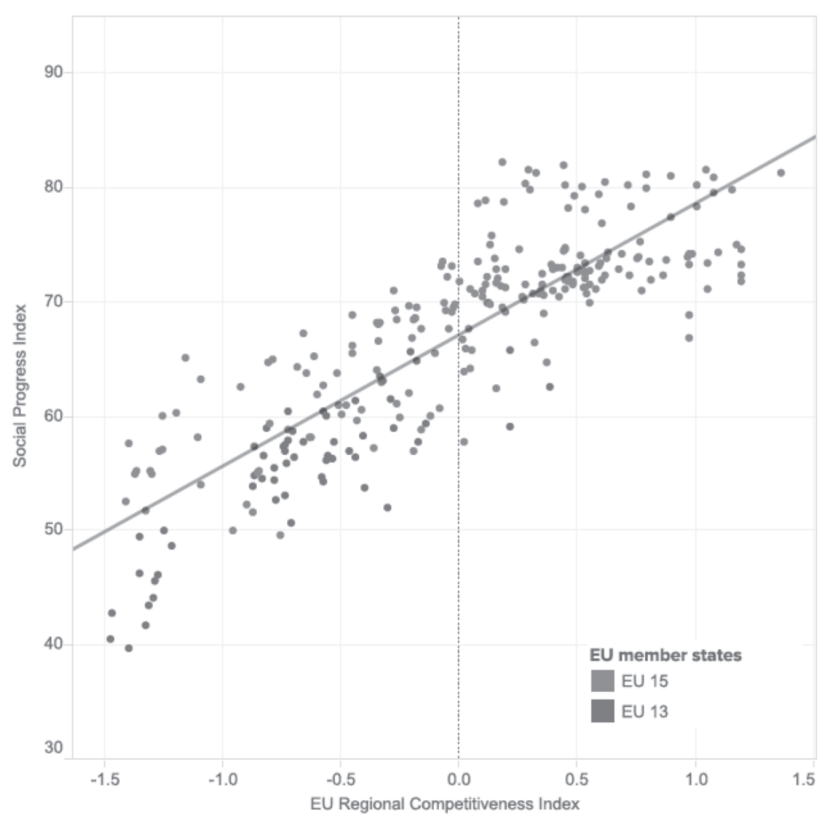

Source: Social Progress Imperative (2016b)

Figure 12. Strength of relationship between regional SPI and competitiveness $\left(R^{2}=0.728\right)$

\section{RAISING INCOMES CAN HELP}

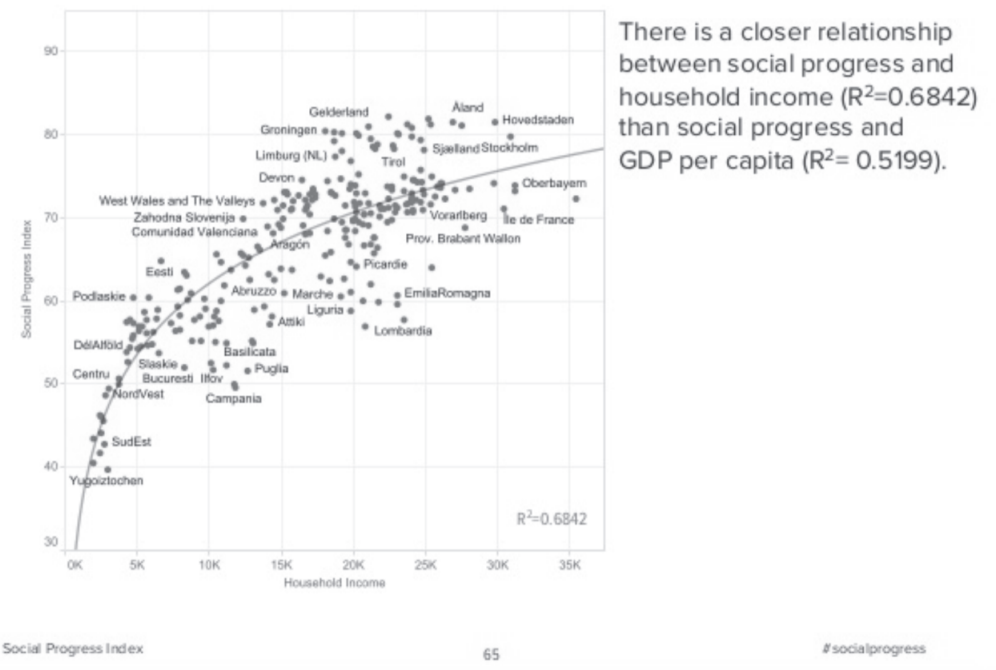

Source: http://www.slideshare.net/socprog/2016-eu-regional-social-progress-index/

Figure 13. Relationship between regional SPI and household income 
However, according to the published regional SPIs, no correlation can be found - on the whole - between the favourable or unfavourable positions of regional social progress results in an international comparison and the majority willingness/voting results as to leave or remain. Based on this finding, searching into the causes behind the majority rejection of integration, we should reasonably go on examining the relationships within the country - locally - first of all. Another question to be analysed is whether behind the willingness to leave we may presume an intention to preserve the social progress results achieved at the given level of economic development.

The presumption that the employment rate does not affect willingness to reject or support integration is also confirmed by the rather weak connection between regional social progress indices and employment (see Figure 14).

\section{UNEMPLOYMENT AND SOCIAL PROGRESS}

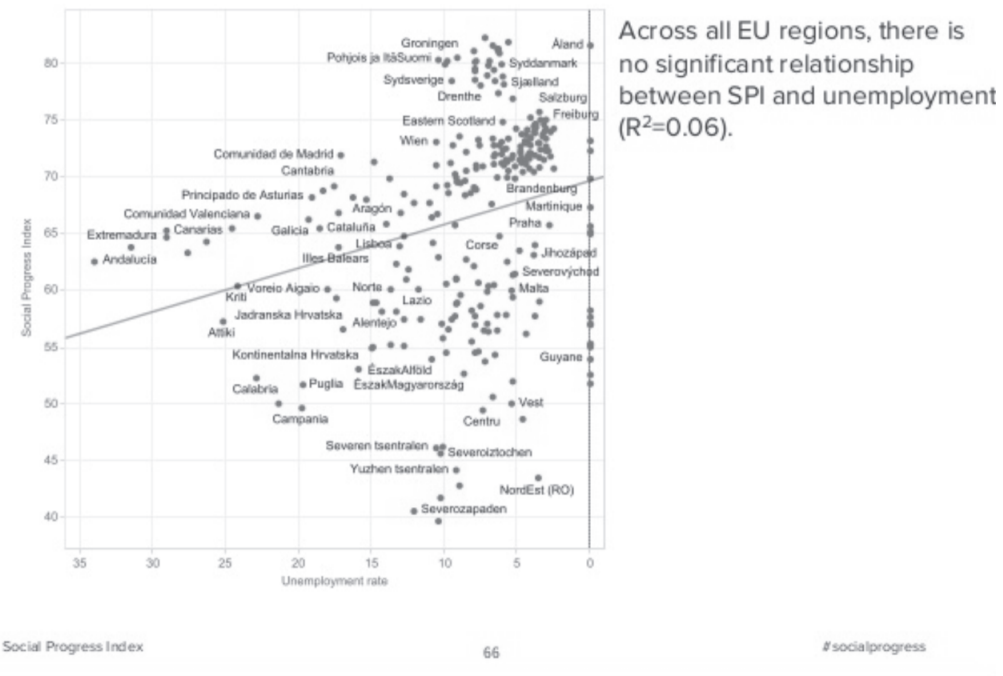

Source: http://www.slideshare.net/socprog/2016-eu-regional-social-progress-index/

Figure 14. Relationship between regional SPI and employment rate

\section{Conclusions with Reference to Factors Affecting EU Integration}

With reference to the European Union, we think of the cohesion policy as a tool applied to eliminate regional, economic, social, cultural, etc. disparities hindering integration - either appreciatively or critically. To put it somewhat simpler (and 
disregarding the other problems in the Eurozone): the more developed core countries are willing to pay contributions towards the 'catch-up' in order to enjoy access to a bigger market and cheaper labour and, as a result, the growth of their own economy. This economic structure - based on recourse to funds received for the illusion of catching up - on the peripheries leads to corruption being reinforced and accepted at the societal level, servant and defenceless roles being fixed within the global value chain with local business competitiveness decreasing.

On the basis of the experience and criticism of the EU's cohesion policy, a strong doubt may arise whether the programmes aimed at convergence, competitiveness, and territorial cooperation for the period of 2007-2013 have - on the whole produced a more favourable effect than if the same resources had been given to the more developed regions, being able to use them more efficiently, for the enhancement of their communication systems meeting their specific functional requirements. In its critical review, the Barca Report of 2009 basically pointed out the low efficiency of applying general (GDP-based) convergence criteria, disregard for specific (local) conditions, and concentration on the distribution of resources rather than on true results (Barca 2009).

If a certain general level of consumption - determined by economic development - can be reached in return for expenditure acceptable to the majority, the 'enjoyment' of social progress results becomes the number one priority for the part (ideally the majority) of the society who are no more interested in or concerned with the exploitation of the benefits arising from economic growth exceeding or just wishing to reach the generally 'accepted' level of consumption. As mentioned earlier, the population of the UK aged over 45 enjoying work-related income or pension at a high standard of living, in other words the bourgeois middle class, is less responsive to arguments proclaiming the possibilities or at least the promise of economic growth exploiting the EU integration - by all means advantageous for the UK as a core country - yet for them not providing (additional) concrete benefits.

On the other hand, in the people arriving e.g. from the historically not colonized territories, such as free employees from the new EU member states - actually employed in areas required for the operation of local economy -, they (mostly generalizing based on false information or half-truths) see aliens jeopardizing their social progress results achieved.

Even about the EU's inefficient cohesion policy they notice not a bad structure formulated along the core countries' interests but income taken away from them and 'handed out' to the unworthy. Considering that in the EU's political phraseology the strengthening of integration and not the improvement of local (!) social progress results is specified as a goal, the existing structural and institutional problems to be solved also devalue integration as an attainable goal. If the integration processes were treated properly - i.e. as a tool instead of a goal -, the subject of communication would be the need to improve solution methods, and not 
the questioning of common goals. That would have been especially important in the case of the population of a country viewing itself with particular 'self-esteem', citing its colonial empire's past and Commonwealth present, and thereby having significant political and economic relationships extending beyond the EU.

Having compared the development disparities examined at regional level, we can come to the conclusion that - rather than suggesting that nationalistic aspirations spreading in Europe are also strengthening within the UK - the Brexit referendum's outcome indicates the problem that even in western liberal democracies there is no widely supported answer to the question of how we can ensure the permanent protection of local social progress results instead of sealing off - which is otherwise damaging to economic relationships and growth -, and thus aiming to isolate and hinder the movement of the increasing percentage of lagging social layers and immigrants.

That explains the 'position' taken up by a middle class continuously losing or fearing to lose its self-esteem and real economic power even in the UK, having a higher education and a lower unemployment rate by European (as well as wider, international) standards.

As the protection and further improvement of social progress results already achieved were not properly emphasized - besides catch-up - in the wording and communication of the policies aiming to strengthen European integration processes when social cohesion between and within the territorial units was set as a goal, the middle classes - exposed to the (real or presumed) risk of falling behind, and not benefitting directly from economic growth yet still being in a favourable financial and social situation - obviously feel the disadvantages of European integration stronger than its advantages. Social, economic, and territorial cohesion being merely interpreted and communicated with an emphasis on the catch-up will appear to players fearing for their previous favourable status as a position against their local interests (linked to everyday life).

Of course, the question can also be asked as follows: Will or can leaving the EU improve the competitive positions of regions with a majority favouring the exit? No exact answer can be given to that as yet. Anyway, ruled out at the present level of economic development (we are talking about the world's $5^{\text {th }}$ largest economy!), the average or better than average English and Scottish economic regions will remain viable and - in international comparisons - competitive outside the established EU-integration framework as well. However, for the less advanced territories with considerably smaller populations, new regional development policies will - presumably - need to be developed.

In connection with the social progress results and global Sustainable Development Goals, we have already mentioned the role of national and regional development programmes for conscious social progress, as a result of which the global improvement of social and environmental results can be implemented 
more favourably compared to the 'business-as-usual'-type operation of a society and economy.

Also large international corporations have recently been increasingly recognizing that the improvement of local social and environmental results creates more stable and profitable business conditions for them as well as for the other actors in global value chains. As the institutions of national and local governments are forced to assume a new attitude to their roles along sustainability goals, the leaders of global value chains are also becoming more open to the formulation of new business models closely linked to a change in the innovation culture. To maintain or enhance their competitiveness and reputation, large international corporations are - willing or not - 'compelled' to address social and environmental problems and to produce local results. So, their role has to be considered crucial also in the reinterpretation of social cohesion.

The question is how the global and local economic actors' innovation-based local social and environmental objectives and results can modify the social cohesion strategies and how the disparities in economic and social development can be measured and evaluated at regional level in addition to a comparison across countries. We have seen that any one indicator in itself is not enough since it does not provide sufficient explanation for either the development disparities or their reasons. Anyway, in addition to GDP per capita, it is worth applying and it is important to apply - such indicators as SPI and Well-Being as well as various indices of social progress.

As a concrete example, the outcomes of the Brexit referendum demonstrate that - in addition to a need to enforce the efficiency-enhancement aspects of integration policies aimed at catching up and traditionally considering increase in productivity and employment as a basis - there is also a need for social and environmental usefulness and the achieved social progress results to be promoted and improved by both the state or community operators and business actors. And that applies not only to lagging regions but also to areas with higher and outstanding levels of economic development.

\section{References}

BARCA, F. 2009. An Agenda for a Reformed Cohesion Policy. A Place-Based Approach to Meeting European Union Challenges and Expectations. Independent Report. http://www.europarl.europa.eu/meetdocs/2009_2014/ documents/regi/dv/barca_report_/barca_report_en.pdf.

DELOITTE. 2015. Social Progress in 2030. Developing beyond Economic Growth. A Report for the Social Progress Imperative. http://www2.deloitte.com/content/ 
dam/Deloitte/global/Documents/About-Deloitte/dttl_socialprogressin2030_ report.pdf.

EUROPEAN COMMISSION DG REGIONAL AND URBAN POLICY. 2016a. European Social Progress Index. http://ec.europa.eu/regional_policy/en/ information/maps/social_progress.

2016b. The EU Regional Social Progress Index: Methodological Note. http:// ec.europa.eu/regional_policy/sources/information/maps/methodological_ note_eu_spi.pdf.

GÁSPÁR, Tamás. 2013. A társadalmi-gazdasági fejlettség mérési rendszerei, Statisztikai Szemle 91(1): 77-92.

GREEN, M. 2015. How We Can Make the World a Better Place by 2030. TEDGlobal, London,Filmed in:September 2015.http://www.ted.com/talks/michael_green_ how_we_can_make_the_world_a_better_place_by_2030?linkId=17951655.

Ipsos MORI. 2014. Perceptions Are Not Reality: Things the World Gets Wrong. https://www.ipsos-mori.com/researchpublications/researcharchive/3466/ Perceptions-are-not-reality-Things-the-world-gets-wrong.aspx.

KÖPECZI-BOÓCZ, Tamás. 2011. Társadalmi indikátorok. A TÁMOP4.1.2/A/2-10/1-2010-0003 Képzés- és tartalomfejlesztés a Budapesti Corvinus Egyetemen c. projekt. Budapest. 1-96.

PORTER, M. E.-KRAMER, M. 2011. The Big Idea - Creating Shared Value - How to Reinvent Capitalism - and Unleash a Wave of Innovation and Growth. Harvard Business Review Jan.-Feb.

SOCIAL PROGRESS IMPERATIVE. 2016a. Social Progress Index 2016 Report. http://www.socialprogressimperative.org/publications.

2016b. 2016 EU Regional Social Progress Index. http://www. socialprogressimperative.org/custom-indexes/european-union/.

SZABÓ, Pál. 2009. Európa térszerkezete különböző szemléletek tükrében. Földrajzi Közlemények 133(2): 121-134.

UNITED NATIONS GENERAL ASSEMBLY, A/RES/70/1. 2015. Transforming Our World: the 2030 Agenda for Sustainable Development. http://www.un.org/ga/ search/view_doc.asp?symbol=A/RES/70/1\&Lang=E. 